J O U R N A L OF

French and Francophone Philosophy
REV U D DE L A

philosophie française et de langue française

\title{
At the Mind's Limits and German-Jewish Symbiosis: Or, Améry on Guilt and the Possibility of Redemption
}

Robert Erlewine

Journal of French and Francophone Philosophy - Revue de la philosophie française et de langue française, Vol XXIV, No 3 (2016) 140-156.

\author{
Vol XXIV, No 3 (2016) \\ ISSN 1936-6280 (print) \\ ISSN 2155-1162 (online) \\ DOI 10.5195/ jffp. 2016. 792 \\ www.jffp.org
}

\section{(c) EY-NC-NO}

This work is licensed under a Creative Commons Attribution-Noncommercial-No Derivative Works 3.0 United States License.

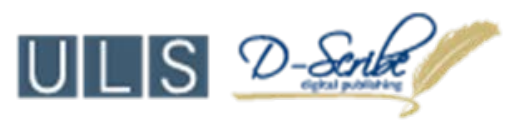

This journal is operated by the University Library System of the University of Pittsburgh as part of its D-Scribe Digital Publishing Program, and is co-sponsored by the University of Pittsburgh Press 


\title{
At the Mind's Limits and German- Jewish Symbiosis
}

Or, Améry on Guilt and the Possibility of Redemption

\author{
Robert Erlewine \\ Illinois Wesleyan University
}

At the 50th anniversary of the Jean Améry's Jenseits von Schuld und Sühne: Bewältigungsversuche eines Überwältigten, published in English as At the Mind's Limits: Contemplations By a Survivor on Auschwitz and its Realities, ${ }^{1}$ this work is garnering increased attention in the Anglophone world. ${ }^{2}$ Perhaps it should not be surprising that there is increased interest in this book at this moment when our attention is repeatedly drawn to the plight of immigrants and exiles, state sanctioned use of torture, and police violence-all themes At the Mind's Limits deals with at length. While this recent attention is certainly appropriate, it nevertheless tends to blur the specific and particular socio-political and cultural contours of the work. Améry becomes a writer about the plight of the victim in general, ${ }^{3}$ such that specificity of his Jewishness is lost and the already submerged theological dimensions of his work remain obscure. ${ }^{4}$

By reading At the Mind's Limits in the context of the over-determined and highly fraught notion of German-Jewish symbiosis, ${ }^{5}$ this essay hopes to situate Améry firmly within the bounds of modern Jewish philosophy. Indeed, while At the Mind's Limits is celebrated for exposing how the social, political and ethical phenomenon of recognition breaks down in atrocity, it also issues nothing less than a call for repentance. I argue in this essay that at the core of At the Mind's Limits lies the possibility, however slight, of redemption.

\section{Améry and the J ewish-German Dialogue}

In order to treat Améry, and At the Mind's Limits in particular, in the context of Jewish philosophy, it is essential discuss what is meant by this term. Philosophy has often been described as fundamentally heterogeneous to 
Judaism, such that 'Jewish' philosophy is the project of reconciling the religious tradition of Judaism with the intellectual insights of the non-Jewish world. ${ }^{6}$ Others such as Steven Schwarzschild claim that there is something inherently 'Jewish' about the way certain philosophers philosophize. "It is not so much a matter of doing Jewish philosophy as doing philosophy Jewishly."7 More recently Aaron W. Hughes and Michael Zank argue that rather than asking about whether or not philosophy is either heterogeneous or indigenous to the Jewish tradition(s), scholars should be cognizant of the historical rootedness and contingencies of that practice we label Jewish philosophy wherever it exists. According to Hughes, Jewish philosophy is or has functioned as - an apologetic endeavor whose goal is to "demonstrate the tradition at its most rational" 8 and to "manufacture" a Judaism "comprehensible to non-Jews." 9 Similarly, Zank emphasizes Jewish philosophy as a particular form of apologetic literature that emerges in response to assimilatory pressures in modernity (particularly modern Germany). ${ }^{10}$

I would like to push the demystificatory accounts of Hughes and Zank a bit further. My claim here is that just as there is no clear, all encompassing definition of Judaism, so too there is not one manner of doing Jewish philosophy. Indeed, like Judaism, the very nature of philosophy is contentious even in-or especially in-academic environments. Rather than search for a definition or essence of Jewish philosophy, it is perhaps better to understand different works as falling in the genre of Jewish philosophy when they engage certain constellations of cultural and philosophical issues. What precisely demarcates a constellation of issues as 'Jewish' cannot be said with any great precision, and certainly not in advance of any specific work under examination. Indeed, given the manner in which history and culture were themselves matters of grave philosophical concern in modern German philosophy and continue to be so in contemporary Continental philosophy more generally, it is problematic to neatly circumscribe Jewish philosophy to those works exclusively treating Jewish theological matters. Thus, in recent years, works by figures such as Heinrich Heine, Franz Kafka, Walter Benjamin, Theodor Adorno, and Hannah Arendt are increasinglyand rightfully so-being incorporated into the canon of 'Jewish philosophy.'

In this essay, I argue that At the Mind's Limits is a work of Jewish philosophy. I do so not merely, or even primarily, on the basis of its unique, existentialist reflections on Jewish identity (although one could), but rather because it constitutes an important philosophical contribution to the debate about the so-called German-Jewish symbiosis. This debate, rich with cultural, social, and theological implications is also an essential-if often tacit-component in many of the major political and philosophical disputes in $2^{\text {th }}$ century Jewish philosophy.

The debate around the so-called German-Jewish symbiosis, or the relationship between Jews and Germans, has its roots in the deep 
commitments to German culture maintained by German Jews. As Paul Mendes-Flohr points out, in the 19 ${ }^{\text {th }}$ century, Jews, in their struggle for "civic equality" found common ground with "the liberal, educated strata of German society" in the shared "pursuit of Bildung and Kultur."11 Middleclass Jews eagerly consumed German high culture. However, this was not simple assimilation or flight from inherited traditions but rather, there was something appealing about German culture for Jews (and not only German Jews). Mendes-Flohr attributes this to certain correlations between "Classical Judaism and German Bildung." He writes:

both have a concept of high culture that attributes an intrinsic, overarching value to education - grounded in canonical texts - and learning; both have a concept of knowledge as anti-eudemonistic and hence affirm knowledge as preeminently serving truth and not principally the promotion of earthly happiness or some instrumental aim; and both uphold an ethical idealism, namely, the conviction that education and the quest for knowledge are properly dedicated to the illumination of what one 'ought' to do in the service of the true and the good. ${ }^{12}$

Perhaps there is no greater testimony to this profound correlation between classical Judaism and German Bildung in that Jewish intellectuals so often used the idiom of German philosophy, particularly that of Kant, to interpret and elucidate the Jewish tradition.

The apotheosis of the complementarity or symbiotic relationship of the German and the Jewish can be found in Hermann Cohen's "Germanism and Judaism with Foundational Observations about the State and Internationalism" (1915). ${ }^{13}$ In this text written in defense of the German war effort in World War I, Cohen argued that Judaism and Germanism were inextricably bound up in their essences - their highest values and highest possibilities and conceptions of themselves. Cohen is not merely arguing that Judaism and Christianity are complimentary, but that Judaism is indispensable to German identity, that the two are fundamentally intertwined. ${ }^{14}$

Perhaps in retrospect, it should not be surprising that Hermann Cohen's notion of the German-Jewish Symbiosis as elucidated in "Germanism and Judaism" was widely vilified. Not only did he voice a strong nationalism in support of the German war-effort in World War I-a stance all-too-susceptible to the familiar stereotype of the myopic German Jew rather common among mid and late 20th century Zionist-inflected thinking - but also his work, like that of Neo-Kantianism in general, forms the backdrop against which so many figures central to contemporary Jewish Studies revolted.15 And yet, Cohen's apotheosis of the affinities of Germanism and Judaism was quite in keeping with the sensibilities of his generation. Cohen's rationalist agenda deeply informs, if often negatively, 
the work of Martin Buber, Franz Rosenzweig and Gershom Scholem, who seek something more 'authentic,' a term which was as much their invention as discovery. ${ }^{16}$

Almost diametrically opposed to the position staked out by Cohen, stands Scholem's famous open-letter "Against the Myth of the GermanJewish Dialogue" (1964) written in the wake of the Holocaust, almost 50 years after "Deutschtum und Judentum." In this piece, Scholem claims: "I deny that there has ever been [...] G German-Jewish dialogue in any genuine sense whatsoever, i.e., as a historical phenomenon. It takes two to have a dialogue, who listen to each other, who are prepared to perceive the other as what he is and represents and to respond to him." 17 Scholem flatly denies anything like this ever took place. He finds at least some fault for this lack of dialogue with the Jews. That is, "the liquidation of the Jewish substance by the Jews themselves must in large part be held responsible for the fact that this dialogue did not come to take place as a historical phenomenon."18 Indeed, one of the great tragedies of the exilic condition, at least as it manifested in Germany, is that the Jews, in their attempt to engage Germans in dialogue, forfeited their identity. Scholem writes: "They are no longer even Jews, in the full sense of an unbroken historical consciousness, who speak here, but rather Jews in flight from themselves." 19 For Scholem, it would seem, for the Jew to participate in German culture, he or she had to negate his or her essential Jewishness. Where Cohen saw Germanism and Judaism as complimentary and even symbiotic, Scholem casts the two terms as exclusive, tragically so, such that so many gifted Jews tore themselves asunder trying to be German.

In the wake of the Holocaust, Scholem does not rule out the possibility of a future relationship between Jews and Europeans, even Germans. Whereas on the one hand, "“[a]bysses are flung open by events," on the other hand, "bridges are built by goodwill. Bridges are needed to pass over abysses; they are constructed; they are the product of conscious thinking and willing." 20 Jews and Germans remain distinct species in Scholem's account, and even if restoring good faith relations will involve "openness... and openmindedness" perhaps more telling is his insistence on "distance" and "respect" which demarcate a fundamental gulf, indeed, an "abyss" 21 between the essential natures of Jews and Germans, respectively.

There is no doubt that both Cohen and Scholem employ 'Jew' and 'German' in essentialist ways that strike the contemporary reader as rather antiquated, as tropes or types. ${ }^{22}$ Christoph Schulte, with a contemporary skepticism, challenges the very terminology at the heart of the controversy regarding Judaism and Germanism. He writes: "what goes by German essence or Jewish essence is necessarily fictitious." 23 Indeed, because terms such as "Jews" or "Germans" are inherently problematic, Schulte recommends that we speak in the "singular." 24 
On one level, Schulte is undoubtedly correct. Given how many different accounts of Judaism and of Germanism have been proffered, and how these accounts are often tendentious and mutually contradictory, one is tempted to banish them to the dustbin of history. And yet, to grasp the power and pathos of the work Améry, who-according to his biographer, even as a boy "dreams of symbiosis," 25 - and whose later work elaborates on an exile that is not merely spatial but also linguistic and cultural, it is necessary to engage the interplay of these fatefully intertwined types even if they are ultimately essentialist and fictitious. Indeed, many political and intellectual developments of the $19^{\text {th }}$ and $20^{\text {th }}$ centuries traded on these essentialized types, as fallacious or wrong-headed as they may be. Schulte's methodological caution is no doubt merited, and yet to engage the work of Jean Améry is to find oneself caught in a world haunted by the typologies of Jew and German, typologies enacted and granted an 'objective' reality during the Third Reich.

Unlike Cohen or Scholem, Améry is not an academic. Indeed, where Cohen and Scholem seek master narratives of Judaism, Améry elucidates a notion of Judaism born from his status as a "catastrophe Jew." 26 Améry does not theorize about Judaism as such, but rather offers an account of Jewish identity that is rooted in his own experience, in his 'I.' 27 Améry's Jewishness is paradoxical, torn, between necessity and impossibility; it also is bound up with an inextricable relationship with the Germans.

However, in order to understand the relationship of Améry's work with German identity, it is imperative to first grasp the manner in which it articulates both the social nature of the individual and the inherent fragility of her identity, whether psychically or culturally construed. If Cohen sees the relationship between Germanism and Judaism as necessary, as inextricable, and Scholem sees it as merely contingent and precarious, in At the Mind's Limits Améry grounds it in a relationship that is both paradoxical and morally significant. That is, in the wake of the Holocaust, Améry insists that there is now an inextricable-yet impossible-moral relationship in the pairing of Jew and German. Indeed his work specifically addresses the German-both of the generation of the perpetrators and those who come after - from the perspective of a Jewish victim. ${ }^{28}$

\section{The Rescinding of Identity and the Loss of the Social World}

At its core, At the Mind's Limits is a prolonged, iterative meditation - or series of meditations - on identity, or more precisely on the repercussions of the negation of identity. Indeed, Améry's meditations, bound up with recognition and the ways in which violence degrades an individual's integrity and even selfhood, are profoundly moral in nature. ${ }^{29}$ One issue at the core of the book is how torture and violence exposes the interconnection between the body and the mind or self. The vulnerability of the lived body is 
inextricably bound up with sociality, with recognition. Améry speaks of a "social world" that trades not merely on mutual toleration between our "fellow man" and 'ourselves' but also on the fundamental recognition of his right to live, of our obligation to "ease his suffering." 30 Elsewhere, Améry elucidates that this social world trades on a notion of "dignity." 31 Dignity, for Améry, is inseparable from "[t]rust in the world," namely: "the certainty that by reason of written or unwritten social contracts the other person will spare me-more precisely stated, that he will respect my physical, and with it also my metaphysical, being. The boundaries of my body are also the boundaries of my self. My skin surface shields me against the external world. If I am to have trust, I must feel only what I want to feel." 32 Yet, this social world, founded as it is on dignity and trust in the world, is undermined in torture and atrocity. ${ }^{33}$

It is noteworthy that in his justly celebrated essay, "Torture," which was written after, and appears later in At the Mind's Limits than, his chapter devoted to his time in Auschwitz, Améry states: "I dare to assert that torture is the most horrible event a human being can retain within himself." 34 Améry describes torture as the inversion of the social world founded upon trust in the world. Améry notes that in torture, the torturer wishes to "realize his own total sovereignty" by "negating his fellow man." That is: "The fellow man is transformed into flesh, and in this transformation he is already brought to the edge of death." Torture represents "the total inversion of the social world, in which we can live only if we grant our fellow man life, ease his suffering, bridle the desire of our ego to expand." 35 If the normal social world is built upon recognition, upon restraining our own sense of self to make room for the other, torture is an "orgy of unchecked self-expansion" whereby the self of the other is negated. ${ }^{36}$ Torture is not merely the denial of recognition but rather it is the active negation of the identity of the tortured by the torturer. ${ }^{37}$

Torture reveals that there is nothing about the subject that is beyond the social world, and in this profound act of negation, there is nothing that cannot be denied and taken away from him or her. Améry writes: "The tortured person never ceases to be amazed that all those things one may, according to inclination, call his soul, or his mind, or his consciousness, or his identity, are destroyed." 38 The victim of torture is reduced to his or her body, but his or her body out of his or her control, all exposed flesh." A slight pressure by the tool-wielding hand is enough to turn the other-along with his head, in which are perhaps stored Kant and Hegel, and all nine symphonies, and the World as Will and Representation [sic]-into a shrilly squealing piglet at slaughter." 39 Indeed, this quote reflects not merely the ease with which the torturer can destroy the victim of torture but it also discloses how this asymmetry - at least in the case of Nazi Germanyextends to the world of culture. 
In Améry's first essay, "At the Mind's Limits," - a translation which does not entirely capture the full significance of the German title of the essay, "An den Grenzen des Geistes" insofar as it fails to do justice to the cultural overtones of the term 'Geist' - he questions the survival value of intellectual and cultural possessions such as a "spiritual frame of reference," [geistigen Referenzsystems] and a "well developed esthetic consciousness." 40 Indeed, the intellect lost its transcendence, its capacity to apply beyond its immediate circumstances and to derive meaning from literature and culture. Améry recounts how one winter evening in the camp something sparked the memory of a Hölderlin poem that had once held great significance for him. Yet, now "[t]he poem no longer transcended reality." It was nothing more than "an objective statement." 41 Similarly, when it came to philosophical ideas: "Where they still meant something they appeared trivial, and where they were not trivial they no longer meant anything." 42 Or as Améry puts it, "nowhere else in the world did reality [Wirklichkeit] have as much effective power as in the camp, nowhere else was reality so real. In no other place did the attempt to transcend it prove so hopeless and so shoddy." 43

This loss of transcendence coupled with the loss of culture, however, extends back to the profound asymmetry between the torturer and the victim of torture- or perhaps better - the total sovereignty of the torturer over the tortured. To return the passage cited above, torture reduces the victim, even if he or she has "stored Kant and Hegel, and all nine symphonies, and the World as Will and Representation [sic]" in his or her head, to "a shrilly squealing piglet at slaughter." 44 Once this horrific deed is done, and "the torturer has expanded into the body of his fellow man and extinguished what was his spirit," the torturer can then "sit down to breakfast or, if he has the desire, have a look in at the World as Will and Representation [sic]." 45 While Améry casts doubt on the cultural and intellectual interests of his particular torturers - i.e., he doubts whether they actually read Schopenhauer's The World as Will and Representationnevertheless, the chasm that exists between he and they carries over into the realm of culture in a way that has direct bearing on the question of to whom does culture-in particular, German culture-belong? Just as the torturer undoes the mind or soul of the victim reducing him or her to sheer flesh through intense physical pain, in the Nazi era the cultural identity of the victims - particularly German Jews - were also erased, or perhaps better, undone.

Throughout At the Mind's Limits, Améry highlights the precariousness of the status of the German Jewish intellectual, or the "Jewish intellectual of German educational and cultural background." 46 In contrast to Germans émigrés such as Thomas Mann, who maintained a distinction between the authentic Germany and the false or bad Germany of his present, confidently identifying himself with the former, German Jews had no such capacity. Unlike Mann, in Auschwitz, the "German-Jewish Auschwitz prisoner" could 
not "claim the German culture as his possession, because his claim found no sort of social justification." 47 An example of this lack of social justification, or more properly, its negation and erasure, can be found in Améry's account of a Jewish prisoner, who, when asked by an SS officer what his profession had been, answered without thinking, "Germanist." The SS officer met this answer with a "murderous outburst of rage." Given the premises of Nazi racial science, it was not merely inconceivable that a Jew could grasp German culture but the very thought of it was an insult to that culture, a degradation of it. Jews and Germans, Jews and Germanism were radically distinct. Regardless of education and achievement in his or her past life, then, "[i]n Auschwitz... the isolated [Jewish] individual had to relinquish all of German culture... to even the lowest SS man." 48

It was not only German culture that was ripped from the German Jewish intellectual, but one was denied one's identity and history, insofar as it had been shaped by that culture. As Améry puts it: "We, however, had not lost our country, but had to realize that it had never been ours. For us, whatever was linked with this land and its people was an existential misunderstanding. What we believed to have been our first love was, as they said there, racial disgrace." 49 This is illustrated poignantly in the example of the poet, Alfred Mombert, and a letter he wrote, while he, like Améry, was interned in Gurs. In this letter Mombert refers to himself as a German poet. Améry challenges Mombert's mode of self-identifying, pointing out that: "only someone who writes poetry not merely in German but also for Germans, upon their express wish, can be a German poet." 50 That is: "His readers of yesterday, who did not protest against his deportation, had undone his verses. When he wrote the tragic letter, Mombert was no longer a German poet." Améry explains that vocations require "the consent of society. But if society repudiates that we ever were [such a thing], then we have never been it." As a result, Mombert "died without a past." 51 That is, even if he had once enjoyed success, had been recognized as a poet, indeed, as a German poet, at the point when he was interned in the Gurs camp, when he was branded as a non-German, as a Jew, by the nation in which he once found his audience, a nation he had to conclude overwhelmingly supported what was taking place, society negated his identity, not just in the present but also the past. 52 And this is true not just for Mombert but for German Jews as a whole, "[t]heir past as a social phenomenon had been retracted by society" and thus "it was impossible to still retain it as a subjective, psychological possession." 53

\section{The Moral Chasm}

The profound asymmetry between perpetrator and victim, torturer and tortured culminates in the reduction of the latter to mere flesh, denuded of his or her mind and spirit but also of culture and past. Torture as Améry 
understands it, as we mentioned above, is not merely a denial of the phenomenon of recognition; it is its inversion. In the wake of atrocity, the unspoken social contract between victim and persecutor, and as we will see, between the victim and the larger society, has been shattered. Throughout At the Mind's Limits, Améry emphasizes the profound disconnect between victim and persecutor. "No bridge leads from the [victims] to the [tormentors]." There is no shared truth, no parity or "parallelism." 54 In his justly celebrated account of resentment, 55 Améry explains that while torture or atrocity involves both the victim and perpetrator insofar as the perpetrator commits the act upon the victim, only the victim suffers the repercussions. While the perpetrator committed the atrocities, it is the victim, in this case, Améry, who is "the captive of the moral truth of the conflict." 56 The victim has been damaged, is nailed to the "cross of his ruined past," unable to look to the future, "while the persecutors of yesterday manage to find it too easy." 57

However, it is imperative to understand that it is not merely the perpetrator who has done violence to the victim-but the larger society of which both parties were once a part-by failing to hold the perpetrator accountable, by failing to protect the victim or express outrage at his or her injury, also causes suffering. Améry frequently links the "torturers" to "those who helped them, and [to] the others, who merely stood by silently." 58 Torture then extends into the social world, and, Améry expresses an ever-renewed loss of trust in the world, which is its basis. If the perpetrator initiated the breakdown of the unspoken social contract, that upon which trust in the world is founded, the bystanders allow this breakdown to take place and therefore are also culpable. This "moral chasm" persists even as both the "victims" and the "hangmen" are gradually dying of old age. ${ }^{59}$ Indeed, this breach persists even after the defeat of National Socialism, and it threatens to extend to future generations. 60 The larger society out of which the victims and the criminals emerged, the society that turned away from the victims and tolerated and even endorsed-if only tacitly - the crimes against them, endures despite subsequent political upheavals. And since it has not faced the moral truth of what happened, the dynamics of the consequences linger.

That is, since the world has moved on, since there is no longer any desire to discuss the atrocities that occurred, the concerns of the victims who desire justice from the perpetrators and the accomplices are unwelcome. The victims now find themselves as "Shylocks, not only morally condemnable in the eyes of the nations, but already cheated of the pound of flesh too." 61 Thus, if not only the perpetrators but also the society at large wish to forget the crimes of the past, then as Améry points out, speaking in his capacity of the victim of atrocity: "I am burdened with collective guilt, I say; not they [i.e., the Germans]." 62 
A moral chasm, a bifurcated social reality, emerges whereby the victim lives at odds with the rest of society. The Jew, negated by the perpetrator and his willing accomplices now takes on a subterranean social identity at odds with the identity of his fellow Germans, and to a lesser, but still significant degree, other Europeans. There is no doubt that for Améry, it is the victims and their "warped state" that have right on their side. 63 To be sure, the victim remains trapped in the past, and is denied access to "the genuine human dimension, the future." 64 The victim is out of step with the "the social and biological time-sense, which is also called the 'natural' one." 65 But for just this reason the victim is moral.

Given the profound sociality of morality, its rootedness in mutual recognition, the chasm between the victim and the perpetrator is immense. Society cast out the victim, rescinded his or her membership, rendered him or her "the quarry of death." 66 The perpetrator, on the other hand, acted with a clear conscience or at least with the backing of society. For this chasm to close, this outrage would have to be undone. That is, since the Nazis retroactively rescinded the victims' German identity, the only way for the victim to heal or be made whole - and thus for the wrong to be made rightwould be to negate the previous negation. However, this can only be done retroactively. There was no negation of negation in history. There was no "German revolution and with it the homeland's strongly expressed desire for [the] return [of the victims]." 67 Rather, the Nazis were defeated by outside forces. As a result, for the moral chasm to close, a retroactive revolution in the name of solidarity with the victims against the persecutors is required.

As I mentioned, a cleft now exists between a moral ordering of time and a biological or social one; the social world is riven between the victim on the one hand and the perpetrators, their accomplices, and everyone else on the other. For Améry, it is the victim, and the victim alone, who possesses "the moral truth of the conflict." 68 Society is not fit to judge, at least not with regard to morality, not only because it abandoned the victim before, but also because it is only concerned with preserving its own existence. One of the great moral insights of Améry's work is that the much derided and condemned feeling of resentment actually possesses a powerful moral truth. It prevents the biological and social orderings of time, orderings that privilege forgetting and eliding the moral reality of past deeds, from having the final word. As Améry puts it: "My resentments are there in order that the crime become a moral reality for the criminal, in order that he be swept into the truth of his atrocity." 69

Indeed, despite the austere and often harrowing tone of Améry's prose, his vision is not entirely desolate. Some modicum of redemption, however remote, remains possible; the moral order, though badly damaged, can be restored. The bifurcation of the social world leaves the victim with what Améry calls "an extreme loneliness." 70 Améry provides the example not 
only of this profound loneliness but also a subsequent restoration of sociality or coexistence with one who committed crimes against him, a Flemish SSman named Wajs who repeatedly struck Améry over the head with a shovel handle. ${ }^{71}$ However, this loneliness, this disruption in the moral fabric of social existence can be rewoven. The victim is not necessarily condemned to be alone with the moral truth of the crimes. After the war, Wajs was tried and executed for his crimes. "When SS-man Wajs stood before the firing squad, he experienced the moral truth of his crimes. At that moment, he was with me-and I was no longer alone."72 Améry continues: "I would like to believe that at the instant of his execution he wanted exactly as much as I to turn back time and undo what had been done. When they led him to the place of execution, the antiman had once again become a fellowman." 73 When the criminal is forced to face his or her crime, when society does not evade its own moral capitulations-or cannot evade them, as when Germany was a pariah state in the first few years after the war, a time Améry remembers blissfully - then this rift in time separating the victim from not only the perpetrator but the rest of society can be resolved, unified and harmonized. However, this process is extremely fragile and partial at best. Yet it, and it alone, provides the possibility of bridging the abyss between victim and perpetrator, and of enabling society to atone for its own failures towards the victims.

\section{Redemption?}

Like Scholem, Améry's work is decisively post-Shoah in nature. And yet, where much of the impetus for Scholem's position can be found in Zionist sensibilities from before the war, Améry's stance on the question of German and Jewish dialogue is entirely bound to the Shoah. His very notion of Jewishness is inextricable from it. ${ }^{74}$ Améry's contribution to the question of the German and Jew certainly pertains to the question of guilt, the Schuldfrage, but it is much more than that. Améry's Jewishness stands as an accusation to the Germans. If Cohen saw Judaism as correlated with (in the technical sense), and thus inextricable from, Germanness, Améry understands his status as a Jew as both a provocation to, and indictment of, the Germans. Only in this capacity, does the "Catastrophe Jew" 75 engender the conditions for the possibility of a just coexistence, for a sort of redemption by negating the negation carried out by the generations involved with Nazism. It offers a way forward, though like the moral possibility transcendentally presupposed by resentment, Améry is ultimately skeptical that it will be realized in actuality. And yet, one should not be mislead by the stoic tone of Améry's writing. At stake here is the possibility of redemption, however attenuated.

Since the Germans seemed - at least to Améry - a united front, their support for Hitler and his murderous regime an unquestionable social 
reality, the quickness with which they were forgiven and reintroduced back into civilization after the war was scandalous for the victims. And since Nazism was not defeated from within, Améry stands as a witness impugning Germany. If, at least from the perspective of the Jewish victim, during the Holocaust "Hitler really was the German people," 76 the negation of the Jews by the Germans the only reality, then Améry seeks to engender a "negation of negation" 77 on the part of the Germans. That is, "[ $t]$ he spiritual reduction to pulp by the German people not only of the books, but of everything that was carried out in those twelve years," can engender "a highly positive, [...] redeeming act." 78 While Amery's animus is driven by his resentment, the refusal to forgive or move on can only be understood against a horizon that includes the possibility of redemption.

There can be a reversal of the past through the lens of the present, the proud perpetrators of yesterday can now become objects of shame, and the Germans of today can express solidarity with the victims. If the victim, with his or her resentments is lonely with the moral truth of the atrocities, if SS man Wajs at the moment of his execution came to share that truth, and like Améry, desired to undo the deeds that had transpired, later generations can concretely manifest the desire to retroactively undo the past. ${ }^{79}$ Améry explains:

[The] two groups of people, the overpowered and those who overpowered them, would be joined in the desire that time be turned back and, with it, that history become moral. If this demand were raised by the German people, who as a matter of fact have been victorious and already rehabilitated by time, it would have tremendous weight, enough so that by this alone it would already be fulfilled. The German revolution would be made good and Hitler disowned." 80

Only this, and not the distancing that comes with time, would allow for a genuine break with the Nazi past. Of course, that redemption is possible should not be understood as meaning it is likely. However, its very possibility is what lends the moral force to the resentment of the victims. Their moral loneliness is an abomination; it should not be.

While At the Mind's Limits trades on the tropes of Jew and German, it is important to note that in its pages Judaism and Germanism are no longer abstract, fixed essences; they are identities grounded in specific events, the results of the ways in which particular communities did or did not offer,or or were themselves denied, recognition. In the wake of the Holocaust, the tropes of 'Jew' and the 'non-Jew,' or the 'Jew' and the 'German,' continue to haunt the present. It is precisely, then, in this sense, that At the Mind's Limits is a work that contributes to the Jewish-German dialogue. Améry's project targets - perhaps primarily - the generation of Germans who came after the Holocaust. ${ }^{81} \mathrm{He}$ is challenging Germans who were children or born after the 
Holocaust to repudiate the Germany of their parents and to side with the victims.

There is no doubt that Améry's work is singular in its illustration of the social dimensions of identity and victimhood. The affront to dignity, if it goes unchecked, lingers for generations. But the very affront provides the possibility for reversal, for turning back to the victim, expressing solidarity with him or her, and disowning those elements of one's tradition-perhaps even one's ancestors - in the name of a redemption. The definitive account of the German Jewish dialogue remains to be written, and is perhaps never fully sealed.

${ }^{1}$ Henceforth I will refer to this text as At the Mind's Limits. Jean Améry, At the Mind's Limits: Contemplations by a Survivor on Auschwitz and its Realities, Trans. Sidney Rosenfeld and Stella P. Rosenfeld (Blooomington: Indiana University Press, 1980). I will offer the pagination for the German J enseits von Schuld und Sühne: Bewältigungsversuche eines Überwältigten (Stuttgart, J . G. Cotta'sche Buchahandlundlung, 1977) with the abbreviation J SS.

2 The last decade alone has seen a significant number of publications devoted to him. See for example, Thomas Brudholm, Resentment's Virtue: Jean Améry and the Refusal to Forgive (Philadelphia: Temple University Press, 2008); Irene Heidelberger-Leonard, The Philosopher of Auschwitz: J ean Améry and Living with the Holocaust (New York: I. B. Tauris \& Co. Ltd, 2010), Magdalena Zolkos, ed. On J ean Améry: Philosophy of Catastrophe (Lanham: Lexington Books, 2011); Jill Stauffer, Ethical Loneliness: The Injustice of not being Heard (New York: Columbia University Press, 2015). J. M. Bernstein, Torture and Dignity: An Essay on Moral Injury (Chicago: University of Chicago Press, 2015).

3 To be fair, Améry would not be averse to the manner in which his work is currently being employed. Indeed, in the "Preface to the First Edition, 1966," of At the Mind's Limits, Améry explains that he seeks to offer "a phenomenological description of the existence of the victim." At the Mind's Limits, xiii / J SS 16. This would seem to imply that while his work is grounded in the specific, he aims to unearthing something more universal.

${ }^{4}$ Both Bernstein's Torture and Dignity, and Stauffer's Ethical Loneliness, are exemplary in this regard. They use Améry's work in the context of other documentation about violence and human rights abuse such that his J ewishness, or more specifically, his tie to a specific J ewish tradition, is at most of secondary importance.

${ }^{5}$ For a helpful summary of this fraught term and the issues around it, see Christoph Schulte's helpful account in "Nitcht nur zur Einleitung: Deutschland und Judentum: Ein Disput unter J uden aus Deutchland," in Deutschtum und J udentum: Ein Disput unter J uden aus Deutschland, Ed. Christoph. Schulte (Stuttgart: Philipp Reclam jun, 1993). 1-28.

${ }^{6}$ The most famous expositor of this position is J ulius Guttmann in his magisterial, Philosophies of J udaism: The History of J ewish Philosophy from Biblical Times to Franz Ronsenzweig (London: Routledge, 1964), 3. One also finds this emphasis on traditional J udaism and Western philosophy in Nathan Rotenstreich, Jewish Philosophy in Modern Times: From Mendelssohn to Rosenzweig (New York: Holt, Rinehart and Winston, 1968) and Michael L. Morgan and Peter Eli Gordon, "Introduction: Modern Jewish Philosophy, Modern Philosophy, and Modern Judaism," in The 
Cambridge Companion to Modern Jewish Philosophy (Cambridge, UK: Cambridge University Press, 2007), 1-13.

7 Steven S. Schwarzschild, "An Agenda for Jewish Philosophy in the 1980's" in Studies in J ewish Philosophy: Collected Essays of the Academy for Jewish Philosophy, 1980-1985 Ed. Norbert Samuelson (Lanham : University Press of America, 1987), 105.

8 Aaron Hughes, Rethinking Jewish Philosophy: Beyond Particularism and Universalism (Oxford University Press, 2014), ix.

9 ,ibid., 4

10 Michael Zank, "The Heteronomy of Modern Jewish Philosophy," J ournal of J ewish Thought and Philosophy Vol 20.1 (2012): Re-Imagining the Historical in Jewish Philosophy: Beyond Historicization, p. 104

${ }^{11}$ Paul Mendes-Flohr, German J ews: A Dual Identity (New Haven: Yale University Press, 1999), 8.

12 lbid. 34-35

13 Hermann Cohen, Deutschtum und J udentum mit grundlegenden Betrachtungen über Staat und Internationalismus," in Hermann Cohens J üdische Schriften II (Berlin: C. A. Schwetschke \& Sohn, 1924), 237-290.

${ }^{14}$ For an extended discussion of Cohen's nationalist writings, see Robert Erlewine, J udaism and the West: From Hermann Cohen to J oseph Soloveitchik (Bloomington, IN: Indiana University Press, 2016), 14-33.

15 To be sure, the text was immediately controversial, criticized by Zionists an antisemites alike. In the hopes of explaining himself further, Cohen wrote "Eine Kritische Nachwort als Vorwort" [A Critical Afterwords as Forward] (1916) and a second version of the essay titled simply "Deutschtum und Judentum" (1916). See Hermann Cohen, "Ein kritisches Nachwort als Vorwort," in Hermann Cohens Jüdische Schriften II (Berlin: C. A. Schwetschke \& Sohn, 1924), 291-301, and the second version of "Deutschtum und J udentum" from 1916 in Hermann Cohens J üdische Schriften II (Berlin: C. A. Schwetschke \& Sohn, 1924), 301-318. For a helpful account of its reception, see see Hartwig Wiedebach, The National Element in Hermann Cohen's Philosophy of Religion, trans. William Templer (Leiden: Brill, 2012), 1-50.

16 Michael Brenner helpfully states: "J ewish culture in Weimar Germany was characterized neither by a radical break with the past nor a return to it. Indeed, it used distinct forms of Jewish traditions, marked them as authentic, and presented them according to the demands of contemporary taste and modern cultural forms of expression. What might have appeared as authenticity was in fact a modern innovation" The Renaissance of J ewish Culture in Weimar Germany (New Haven, CT: Yale University Press, 1996), 5.

${ }^{17}$ Gershom Scholem, "Against the Myth of the German-J ewish Dialogue," in On J ews and J udaism in Crisis: Selected Essays, Ed. Werner J. Dannhauser (New York: Schocken Books, 1976), 61-62.

${ }^{18}$ Gershom Scholem, "Once More: The German J ewish Dialogue," in On J ews and J udaism in Crisis: Selected Essays, Ed. Werner J. Dannhauser (New York: Schocken Books, 1976), 68.

19 Ibid. , 69

${ }^{20}$ Gershom Scholem, "J ews and Germans," in On J ews and J udaism in Crisis, 91

21 ibid. , 91 
22 For a critique of this way of thinking, see Daniel Boyarin and Jonathan Boyrarin, "Diaspora: Generation and Ground of J ewish Identity," Critical Inquiry 19, no. 4 (Summer 1993), pp. 693725 .

${ }^{23}$ Christoph Schulte "Nitcht nur zur Einleitung," 13

${ }^{24}$ Ibid., 17

25 Irène Heidelberger-Leonard, The Philosopher of Auschwitz, 12

${ }^{26}$ J ean Améry, At the Mind's Limits94 / J SS 147. In regard to Cohen and Scholem, David Biale's, Gershom Sholem, Kabbalah and Counter-History, $2^{\text {nd }}$ ed. (Cambridge: Harvard University Press, 1982), highlights at several points, the dialectical relationship between Scholem's method and Cohen's. See especially page 88.

${ }^{26}$ Ibid, 94 / J SS 147

${ }^{27}$ See J ill Stauffer, Ethical Loneliness, 11-17 for, among other things, a discussion of Améry's use of the word 'I.' For a discussion the Judaic, biblical elements of Améry's first person witness, see Aleksandra Ubertowska "The Wounded Subject, Anagram: On the Philosophy of 'Subjectivity after Auschwitz'" in Améry's Work in On J ean Améry, p. 6.

${ }^{28}$ Améry's two "Prefaces" specifically address his German contemporaries. Also, see J ean-Michael Chaumant, "Geschichtliche Verantwortung und menschliche Würde bei Jean Améry," in Über Jean Améry (Heidelberg: C. Winter, 1990), 29-47 and Irène Heidelberger-Leonard, The Philosopher of Auschwitz, 133-166.

${ }^{29}$ Here I would disagree with J. M. Bernstein's account of Améry's At the Mind's Limits in Torture and Dignity. Bernstein writes: "Améry's confession and description of the essential elements of his existence as victim are what makes his account invaluable; because it is the existence of the victim that absorbs him, questions of ethics and morality recede almost to the point of disappearance. By focusing on the experience of torture, Améry makes available to us a phenomenological profile, a philosophical ethnography of a paradigmatic grievous moral wrong without the coding or presuppositions of moral theory (about which, anyways, Améry would have been harshly skeptical.)"(76). There is no doubt that Améry provides a profound phenomenological investigation, as Bernstein describes. However, there is also, as I will highlight shortly, a significant moral horizon to this investigation.

30 lbid, 35/ J SS 66. I am using the male pronoun to keep with the Améry's word choice.

${ }^{31}$ lbid., 28/ J SS 56

32 Ibid., 28/ J SS 56

${ }^{33}$ See Bernstein, Torture and Dignity, 39

${ }^{34}$ At the Mind's Limits, 22/ J SS 48

$35 \mathrm{lbid}, 35$ / J SS 66

${ }^{36} \mathrm{lbid}$., 36 / J SS 67

${ }^{37}$ For an alternate reading of Améry's discussion of torture, see Bernstein, Torture and Dignity, 99115.

38 Ibid., 40/ J SS 73 
39 lbid., 35 / J SS 66 - Note that the translators are in keeping with the original when they do not italicize The World as Will Representation, a work of philosophy by Arthur Schopenhauer.

40 Ibid, $2 /$ J SS 19; For a nice account of the intellect in Améry, see Kitty J. Millet, "Contemplating J ean Améry's Loss of Transcendence," in On J ean Améry, 21-39.

${ }^{41}$ Ibid., $7 /$ J SS 26

42 lbid., 19/ J SS 43

${ }^{43}$ Ibid., 19/ J SS 43, See Millet, "Contemplating J ean Améry's Loss of Transcendence," p. 23 for a discussion of the significance of the term Wirklichkeit.

${ }^{44}$ Améry, At the Minds Limits, 35/ J SS 66

45 Ibid., 35/ J SS 67

${ }^{46}$ Ibid., 8/ J SS 27

${ }^{47} \mathrm{lbid}$., 8 / J SS 28

${ }^{48}$ Ibid., 8 / J SS 28

49 lbid., 50 / J SS 86

50 lbid., 60/ J SS 100

51 lbid., 60 / J SS 101

52 In regard to the notion of presuming collective support for Hitler, and thus, addressing the issue of collective guilt, Améry writes, "The far-too-many were not SS men, but rather laborers, file clerks, technicians, typists-and only a minority among them wore the party badge. All in all, for me they were the German people. What was taking place around them and with us, they knew exactly. For they perceived the burnt smell from the nearby extermination camp as we did, and some wore clothes that only the day before had been taken on the selection ramps from the arriving victims.... They found that everything was just right, and I am dead certain they would have voted for Hitler and his accomplices if at that time, 1943, they had stepped up to the ballot box. Workers, petty bourgeois, academics, Bavarians, Saarlanders, Saxons: there was no difference. Whether the victim wanted to or not he had to believe that Hitler really was the German people." The few people who did stand out and help "did not stand a chance of prevailing against the mass of people." (At the Mind's Limits, 74/ J SS 118-119)

${ }^{53}$ Améry, At the Minds Limits, 59/ J SS 99.

54 Ibid., 34/ J SS 64-65

${ }^{55}$ The German text uses the term Ressentiment, which makes sense, in that in many ways it is a prolonged response to Nietzsche. For a discussion of Améry's thought vis-à-vis Nietzsche's, see Jill Stauffer, Ethical Loneliness, 113-126. Also, see Thomas Brudholm's extended treatment of Améry's account of resentment, Resentment's Virtue. My reading of Améry in this section is indebted to Bruhdholm's.

${ }^{56}$ Améry, At the Minds Limits, 70/ J SS 112-113

${ }^{57}$ Ibid. 69/ J SS 111

${ }^{58} \mathrm{Ibid} .$, 70/ J SS 113

59 lbid., ix / J SS 10 
60 In many ways this essay is treading on ground first plowed by Jean-Michael Chaumant in his fascinating essay, "Geschichtliche Verantwortung und menschliche Würde bei J ean Améry."

61 lbid., 67 / J SS 109

$62 \mathrm{lbid}$., 75/ J SS 120

${ }^{63} \mathrm{lbid}, 68$ / J SS 110

${ }^{64} \mathrm{Ibid}$., 68/ J SS 111

65 Ibid., 72/ J SS 115

66 Ibid., 85 / J SS 134

67 lbid., 51/ J SS 88

68 Ibid., 70 / J SS 113

69 lbid., 70 / J SS 113

$70 \mathrm{lbid}$., 70/ J SS 114

$71 \mathrm{lbid}, 70$ / J SS 113

72 Ibid., 70/ J SS 114

${ }^{73}$ Ibid 70/ J SS 114

${ }^{74}$ Indeed, in his essay, "Being a J ew," in Radical Humanism: Selected Essays, Eds. And Trans. Sidney Rosenfeld and Stella P. Rosenfeld (Bloomington, IN: Indiana University Press, 1984), 17, Améry concludes, in retrospect, his participation in a resistance movement in Belgium-which ultimately lead to his internment at Auschwitz-was "only an unconscious attempt to evade the J ewish identity that I had long since taken upon myself intellectually.... It was my last, absurd effort to escape a collective fate."

75 Ibid., 94 / J SS 147

${ }^{76}$ Ibid., 74/ J SS 119

$77 \mathrm{lbid}$, , 79/ J SS 125

$78 \mathrm{lbid}$, , 79/ J SS 125

79 Brudholm, Resentment's Virtue, 114. As Brudholm puts it, the Germans should come to "share with the survivors the impossible wish that what happened had not happened."

${ }^{80}$ Améry, At the Mind's Limits, 78/ J SS 124-125

${ }^{81}$ On the claim that we should see Améry's audience as the younger generation of Germans, see Chaumant in his, "Geschichtliche Verantwortung und menschliche Würde bei Jean Améry," and Brudholm, Resentment's Virtue, 104-117. 